\title{
DETERMINATION OF THE STRUCTURE OF ACUTE INJURY OF TEMPORARY AND PERMANENT FRONTAL TEETH IN CHILDREN, ANALYSIS OF DIAGNOSTIC AND TREATMENT MEASURES AND THEIR EFFECTS
}

D0I: 10.36740/WLek202004121

\author{
Valentina P. Trufanova, Olha V. Sheshukova, Natalia A. Lyakhova, Tetiana V. Polishchuk, Sofia S. Bauman, \\ Stanislav 0. Stavytskyi \\ UKRAINIAN MEDICAL STOMATOLOGICAL ACADEMY, POLTAVA, UKRAINE
}

\begin{abstract}
The aim: To determine the structure of acute injuries of temporary and permanent frontal teeth in children, to analyze the applied diagnostic and treatment measures for acute tooth trauma and to investigate their effectiveness.

Materials and methods: The subject of the study were 31 children aged 2-12 years with acute temporary and permanent tooth trauma. Methods: clinical (radiological, thermodiagnosis), medical and statistical.

Results: The number of injured permanent teeth was greater than the number of injured temporary teeth. The pattern of temporary and permanent tooth injuries differed, so in temporary teeth dislocations were observed, and in permanent teeth fractures prevailed over dislocations. In our opinion, this is due to the peculiarities of the anatomy of the temporary teeth. Usually, the therapeutic tactics of acute temporary teeth injuries is to remove them, despite their important role in the growth and development of jaws, physiological formation and eruption of permanent teeth. The therapeutic tactics of dynamic observation in the case of intrusive dislocation of the temporary tooth were selected in the clinic of the Department of Pediatric Dentistry. In some cases, with a slight change in the position of the temporary tooth, self-regulation of its position was observed, in other cases the tooth remained dystopic, but its viability remained in $50 \%$ of cases.

Therapeutic tactics of acute injuries of permanent teeth were selected according to the type of trauma. In the case of permanent tooth dislocation, with a slight change in its position, tooth immobilization was carried out by splinting with fiberglass tape and photopolymer composite material.

Conclusions: Our observations have shown that the complex of modern specialized medical care for the affected children with acute traumatic injuries of the teeth should be guided by their preservation, which ensures the subsequent normal formation of the dental-jaw apparatus. To ensure these conditions, a long, reliable immobilization of the damaged tooth is required as soon as possible after injury.
\end{abstract}

KEY WORDS: acute injury of the front teeth in children, splinting in the early stages

Wiad Lek. 2020;73(4):737-742

\section{INTRODUCTION}

Among the increasing number of odontological pathologies, acute tooth trauma is widespread in various age groups, but it has the highest incidence in children. In childhood, tooth trauma is a cause of emergency treatment for children and has varying degrees of severity. According to literature sources [1] traumatic injuries of teeth are found in $41-50 \%$ of children of preschool age and 26-33\% of school age group.

Injuries of temporary teeth are more often observed in 2-3-year-old children, which is connected with their curiosity, desire for independence and inexperience in combination with lack of protective and instability of neuromuscular reflexes. Injuries of permanent teeth are more common at the age of 8-12 years, which is caused by the formation of a child in the team, the beginning of active sports, the lack of proper control over the behavior of children by parents, caregivers and educators [2].
The main cause of acute tooth trauma is the fall of over-active children during disorganized games, receiving blows to various objects during playing games and power sports, road injuries, conflicts among peers. Also an important factor that leads to tooth trauma is incorrect occlusion or wrong bite. In children with distal occlusion, damage to the anterior upper teeth occurs 2.5 times more often than in children with orthognathic occlusion [3]. Permanent teeth are more stable in the jaw due to the root / crown ratio (even with an unformed root), so the most common permanent tooth injury is a fracture of the crown or root. Traumatic injuries of molars and premolars occur much less frequently, in most cases they are combined with fractures of the jaw and alveolar processes [4].

Diagnosis of acute tooth trauma in children usually does not cause much difficulty because of its obviousness and is based on complaints, anamnestic data of the causes and circumstances of trauma and the results of objective exam- 
ination. In all cases of trauma of the hard tissues of teeth, there are important to make thorough clinical examination of the oral cavity of the child by topographic zones and additional methods of investigation: radiological, electroodontometric, thermometric. However, the diagnosis of dental injuries in children of 2-4 years old has some difficulties, because it is hard to collect a medical history and to conduct a clinical examination at this age. It is quite difficult, and sometimes impossible, to carry out additional research methods (thermal- and electroodontodiagnosis, radiological examination). [4].

Thermodiagnosis in young children allows you to conduct and more clearly determine the state of the pulp, because the sensations that arise when changing temperature stimuli are more familiar and understandable to the child than the sensations that occur when conducting electrodontal diagnostics. An important condition is the dynamic observation, since the prolonged (over a month) absence of tooth reaction to the influence of temperature stimuli can suggest the development of pulp necrosis [2]. Electroodontodiagnosis can be a plausible method of investigation only when carried out on teeth with fully formed root, that is, in a rather limited period of time on temporary teeth (period of root stability) and in permanent ones after full root formation. The period of stability of the root of the temporary tooth falls at the age of the child within 3-7 years, and it is during this age period that the children are little contact and unable to objectively describe the sensation and respond to irritation of the pulp.

In permanent mature teeth, it is advisable to determine the electrical excitability of the pulp, however, this investigation should be carried out not earlier than 2 hours after injury and then every $10-12$ days [5]. The results obtained immediately after the injury are not indicative or decisive. Usually at the first visit there is a decrease in the sensitivity of the pulp of the damaged tooth, which does not always indicate significant damage to the vascular-nerve bundle and can be caused by the pulp shake, compression of the resulting hematoma, or be the result of traumatic neuritis. In the latter case, the restoration of the electrical excitability of the pulp to normal can occur no earlier than a month or even later. At the same time, maintaining the parameters of electro-periodontal examination within normal limits in the primary treatment does not exclude the occurrence of inflammation and death of the pulp in the future. Thus, the results of electro-periodontal examination obtained at the first visit to the doctor are temporary and should be used to compare with the data obtained in the dynamics observation [5].

In the case of tooth trauma, a radiological examination of the child is obligatory, since on its basis the doctor makes diagnostics, prepares a treatment plan, predicts the result and determines the effectiveness and consequences of the conducted treatment. Prolongation of the root of the tooth, thickening of its walls, reduction of the width of the canal and the apical opening are the radiological criteria for maintaining the viability of the pulp [2, 6-10].

The emergence of new clinical features in the dynamics of observation (intensification of the inflammatory process after 2 - 3 days or a longer period after trauma, darkening of the crown of the tooth, fistula formation and the presence of destruction of bone tissue and apex of the root, which is determined radiographically) also characterize the state of the pulp.

Comparison of clinical data and data of additional examination methods, which are considered depending on the age of the child and the degree of damage to the adjacent tissues, allow the doctor to choose the most optimal observation tactics or rational methods of treatment that promotes tooth formation, alveolar structures and jaw growth.

\section{THE AIM}

To determine the structure of acute injuries of temporary and permanent teeth in children who went to the clinic of the Department of Pediatric Dentistry, to analyze the applied diagnostic and treatment measures for acute tooth trauma and to investigate their effectiveness.

\section{MATERIALS AND METHODS}

The subject of the study were 31 children aged 2-12 years with acute temporary and permanent tooth trauma. The examination and treatment were performed in the clinic of the Department of Pediatric Dentistry on the basis of the City Pediatric Dental clinic in Poltava.

Clinical examination of the oral cavity by topographic areas was performed on each child. To assess the condition of the tooth pulp after the injury was performed thermodiagnosis. Cold water or a stream of cold air were used to conduct the thermal test. Depending on the child's age and psycho-emotional state, either panoramic radiography or intra-oral contact radiography was performed. The condition of the pulp was determined by a special apparatus Pulp Test-pt 1 «B1000 Pulpen», Denmark; intraoral contact radiography was performed by a dental X-ray apparatus $5 \mathrm{D}_{2}$ Actyubrentgen», USSR; panoramic radiography was performed on the apparatus Ortohophos XG 5 DS/DS Ceph, «Sirona», Germany.

The treatment of acute permanent tooth injuries was performed by using of suture structures (fiberglass tape or cord) Polyglas, (manufacturer of "ECTA", Ukraine) and of photopolymer composite "Latelux Flow" (manufacturer "Latus", Ukraine).

Evaluation of diagnostic and treatment results was performed by using the standard software package Statistska 6.0 for Windows (StatSoftInc., USA).

\section{RESULTS AND DISCUSSION}

The clinic of the Department of Pediatric Dentistry appealed to 31 children with a total of 54 teeth with acute trauma (Table 1). The reason for going to the doctor in children 2-5 years was injured of temporary teeth, among children 7-12 years - trauma of permanent teeth. In our 
Table I. Structure of acute injuries of temporary and permanent teeth in children.

\begin{tabular}{|c|c|c|c|c|c|c|c|c|c|c|c|}
\hline \multirow[b]{2}{*}{ 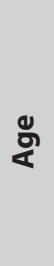 } & \multirow[b]{2}{*}{ 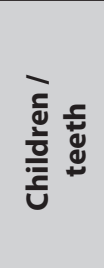 } & \multicolumn{2}{|c|}{ Tooth Injury } & \multicolumn{2}{|c|}{$\begin{array}{l}\text { Fracture of the } \\
\text { root }\end{array}$} & \multicolumn{2}{|c|}{$\begin{array}{l}\text { Fracture of the } \\
\text { crown }\end{array}$} & \multicolumn{2}{|c|}{$\begin{array}{l}\text { Incomplete } \\
\text { dislocation }\end{array}$} & \multicolumn{2}{|c|}{ Full dislocation } \\
\hline & & 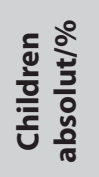 & 䋨 & 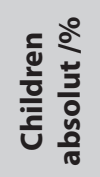 & 竎 & 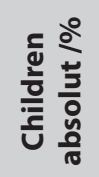 & 䍃 & 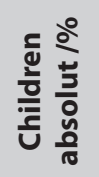 & 竎 & 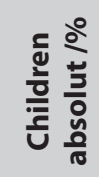 & 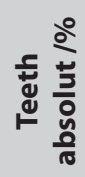 \\
\hline 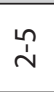 & $\begin{array}{l}9 / \\
15\end{array}$ & $\begin{array}{c}9 / \\
29,03\end{array}$ & $\begin{array}{c}9 / \\
27,8\end{array}$ & - & - & - & - & $\begin{array}{c}9 / \\
29,03\end{array}$ & $\begin{array}{c}14 / \\
25,92\end{array}$ & $\begin{array}{c}1 / \\
3,22\end{array}$ & $\begin{array}{c}1 / \\
1,85\end{array}$ \\
\hline$\frac{n}{1}$ & $\begin{array}{l}22 / \\
39 \\
\end{array}$ & $\begin{array}{c}22 / \\
70,97\end{array}$ & $\begin{array}{c}22 / \\
72,22 \\
\end{array}$ & $\begin{array}{c}6 / \\
19,4 \\
\end{array}$ & $\begin{array}{c}9 / \\
16,7 \\
\end{array}$ & $\begin{array}{r}10 / \\
32,3 \\
\end{array}$ & $\begin{array}{c}17 / \\
31,48 \\
\end{array}$ & $\begin{array}{c}5 / \\
16,1 \\
\end{array}$ & $\begin{array}{c}9 / \\
16,7 \\
\end{array}$ & $\begin{array}{l}3 / \\
9,7\end{array}$ & $\begin{array}{c}4 / \\
7,41 \\
\end{array}$ \\
\hline$\stackrel{i}{i}$ & $\begin{array}{l}31 / \\
54\end{array}$ & 100 & $\begin{array}{l}31 / \\
100\end{array}$ & $\begin{array}{c}6 / \\
19,4\end{array}$ & $\begin{array}{c}9 / \\
16,7\end{array}$ & $\begin{array}{c}10 / \\
32,3\end{array}$ & $\begin{array}{c}17 / \\
31,48\end{array}$ & $\begin{array}{c}13 / \\
45,13\end{array}$ & $\begin{array}{c}23 / \\
42,62\end{array}$ & $\begin{array}{c}4 / \\
12,92\end{array}$ & $\begin{array}{c}5 / \\
9,26\end{array}$ \\
\hline
\end{tabular}

Table II. Distribution of injured teeth by age of child and type of trauma

\begin{tabular}{|c|c|c|c|c|c|c|c|c|c|}
\hline \multirow[t]{2}{*}{$\begin{array}{l}\text { Age, } \\
\text { years }\end{array}$} & \multirow[t]{2}{*}{$\begin{array}{l}\text { Children/ } \\
\text { teeth }\end{array}$} & \multicolumn{2}{|c|}{$\begin{array}{l}\text { Fracture of the root, } \\
\text { teeth }\end{array}$} & \multicolumn{2}{|c|}{$\begin{array}{l}\text { Fracture of the crown, } \\
\text { teeth }\end{array}$} & \multicolumn{2}{|c|}{$\begin{array}{c}\text { Incomplete } \\
\text { dislocation, teeth }\end{array}$} & \multicolumn{2}{|c|}{$\begin{array}{c}\text { Full dislocation } \\
\text { teeth }\end{array}$} \\
\hline & & $\mathrm{t}$ & $p$ & $\mathrm{t}$ & $p$ & $t$ & $p$ & $\mathrm{t}$ & $p$ \\
\hline 2 & $4 / 8$ & & & & & 7 & & 1 & \\
\hline 3 & $3 / 5$ & & & & & 5 & & & \\
\hline 4 & $1 / 1$ & & & & & 1 & & & \\
\hline 5 & $1 / 1$ & & & & & 1 & & & \\
\hline \multicolumn{10}{|l|}{6} \\
\hline 7 & $5 / 10$ & & & & 4 & & 4 & & 2 \\
\hline 8 & $6 / 8$ & & & & 6 & & 1 & & 1 \\
\hline 9 & $3 / 5$ & 2 & & & & & 2 & & 1 \\
\hline 10 & $3 / 7$ & 2 & & & 5 & & & & \\
\hline 11 & $2 / 4$ & 2 & & & 2 & & & & \\
\hline 12 & $3 / 5$ & 3 & & & & & 2 & & \\
\hline TOTAL & $31 / 54$ & 9 & & & 17 & 14 & 9 & 1 & 4 \\
\hline
\end{tabular}

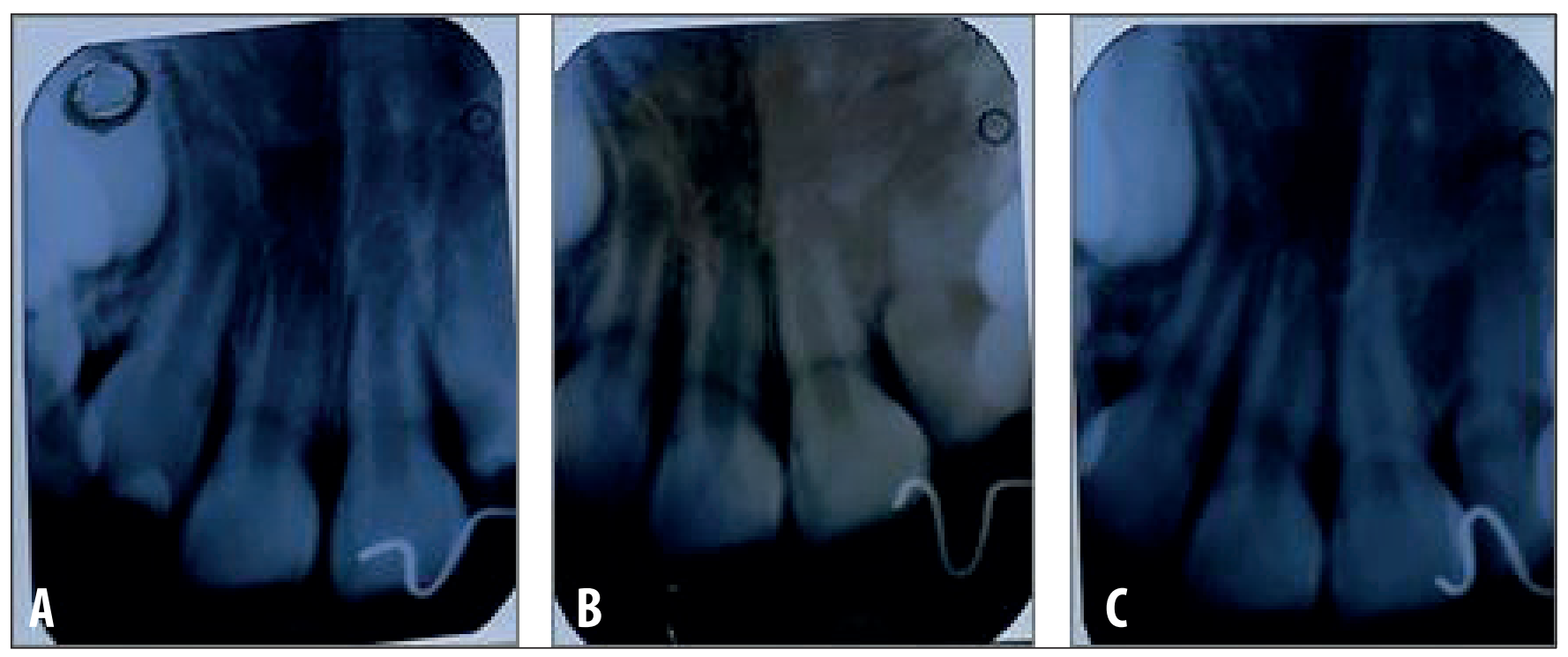

Figure 1. X-ray of a 7 year-old patient with incomplete dislocation (extrusion) of 11th and 21st teeth: immediately after trauma (a); after 1 month (b); after 3 months (c). 

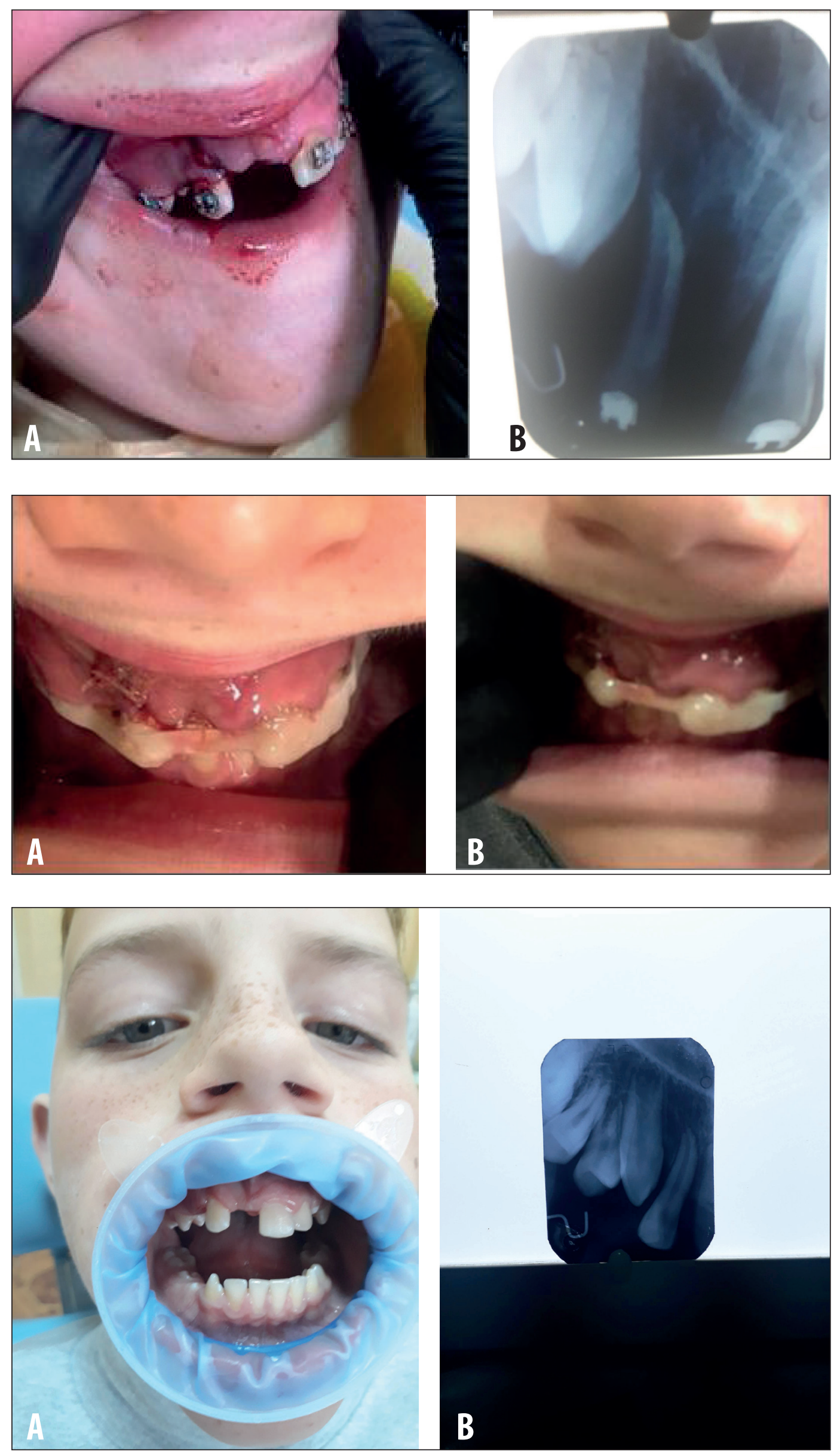

Figure 2. Appearance (a) and target X-ray (b) of patient M., 8 years old, with incomplete dislocation (extrusion) of 12th and 21st teeth and full dislocation (avulsion) of 11th tooth.

Figure 3. Appearance of a 8 years-old patient with incomplete dislocation (extrusion) of the 12th and 21st teeth, and full dislocation (avulsion) of the 11th tooth. Splinting is performed by using of fiberglass tape $(a, b)$.

Figure 4. Appearance (a) and contact radiograph (b) of patient M., 8 years old, with incomplete dislocation (extrusion) of the 12th and 21st teeth, full dislocation (avulsion) of the 11th tooth after removal of the tire. 
previous studies, we identified an increase in the number of removed temporary teeth in a period of 2007 to 2017 years [13]. In our opinion, this situation may be related to the increase in the number of complicated caries of temporary teeth and the fact that temporary teeth in children during the alternating bite in the case of trauma are removed without attempting to preserve.

Temporary tooth injuries were reported less frequently than permanent teeth $(29.03 \%$ and $70.97 \%$ of cases, respectively) (Table I).

The number of injured permanent teeth was greater than the number of temporary teeth (39 and 15 teeth, respectively). On average: 1.67 temporary teeth and 1.26 permanent teeth were injured per one child.

The structure of temporary and permanent tooth injuries varied: in the temporary teeth, full and incomplete dislocations were predominantly observed, and in the permanent teeth fractures prevailed over the dislocations (Table 2). In our opinion, this is due to the peculiarities of the anatomy of the temporary teeth, namely the ratio of the height of the crown to the length of the root part. Almost all cases of dislocation were intrusive (temporary teeth $-29.03 \%$, permanent teeth $-16.1 \%$ ). Full dislocation occurred much less frequently: $3.22 \%$ of temporary teeth and $9.7 \%$ of permanent teeth (Table II).

The location of the fractures in the permanent teeth was different: the root fracture was diagnosed in six children, accounting for $19.4 \%$, the fracture of the root of two teeth was diagnosed in three children, and among the lesions of the tooth crown prevailed the fractures within the crown part, namely dentin, (32.3\%).

Usually, the therapeutic tactics of acute temporary teeth injuries is to remove them, despite their important role in the growth and development of jaws, physiological formation and eruption of permanent teeth. The therapeutic tactics of dynamic observation in the case of intrusive dislocation of the temporary tooth were selected in the clinic of the Department of Pediatric Dentistry. In some cases, with a slight change in the position of the temporary tooth, self-regulation of its position was observed, in other cases the tooth remained dystopic, but its viability remained in $50 \%$ of cases.

Therapeutic tactics of acute injuries of permanent teeth were selected according to the type of trauma. In the case of permanent tooth dislocation, with a slight change in its position, tooth immobilization was carried out by splinting with fiberglass tape (cord) Polyglas (manufacturer of "ECTA", Ukraine) and photopolymer composite material "Latelux Flow" (manufacturer "Latus", Ukraine), without repositioning it; with significant displacement of the tooth, its reposition and immobilization was carried out by a similar technique, with subsequent dynamic observation (radiological examination, thermo- and electroodontodiagnosis). The splinting of 9 dislocated teeth was performed, while the teeth remained vital, and dynamic observation was performed after 1 and 3 months. Dental viability was determined by the reaction of the tooth to temperature stimuli and some radiological features, such as its subsequent growth and root formation.
Here is one of the cases of acute injury of the front teeth of the upper jaw. In the clinic of the Department of Pediatric Dentistry parents approached with an 8-year-old boy who had a braces system on the teeth of the upper jaw and who had been injured in the gym contacted the front teeth of the upper jaw for a volleyball net. On examination revealed: the 11th tooth is missing, the 12th tooth is significantly displaced vestibularly, the 21 st tooth is slightly displaced toward the missing 11th tooth. There are braces on the teeth, and there is no arch (Figure $2 \mathrm{a}$ ). On a radiograph (Figure $2 \mathrm{~b}$ ): the 12th tooth is considerably "elongated", its root is exposed 2/3; The 21st tooth is displaced, there is a cleavage of the medial and outer walls of the hole of the 11th tooth.

Diagnosis: incomplete dislocation (extrusion) of the 12th and 21st teeth, full dislocation (avulsion) of the 11th tooth, detachment of the outer cortical plate of the alveolar process in the area of the missing 11th tooth.

Using infiltration anesthesia, the reposition of the 12th, 21 st teeth and the external cortical plate of the alveolar process were performed; the wound is sutured with a catgut suture; tooth immobilization was performed by applying a fiberglass tire and photopolymer composite material (Figure 3a, 3b).

Prescriptions: anti-inflammatory therapy, thorough hygiene of the oral cavity, dynamic observation (re-examination after 2 weeks).

After 2 weeks there were no complaints, examination of the oral cavity revealed: 11 th tooth missing, 12 th and 21 st teeth in the dental arch, on the teeth 14,12, 21, 22, 24 - a fiberglass tire that meets the clinical requirements (tightly fixed on all teeth, without signs of delamination). Oral mucous membranes of normal (pale pink) color, wound clean, remnants of catgut suture.

A review after 1 month made it possible to determine that the tire could be removed. After removal of the tire: the 12th and 21st teeth are stable, the percussion is painless, the reaction to the thermal stimuli is negative, the mucous membrane in the area of projection of the roots of the 12th and 21st teeth is dense, pale pink (Figure 4a). On the radiograph, the periodontal cleft is unchanged, the closing cortical plate of the hole of the 12th tooth is dense, continuous, has a uniform contour throughout the length (Figure $4 \mathrm{~b}$ ).

The patient is referred to an orthodontist to replace a defect in the dentition. The control medical examination is scheduled after 3 months.

\section{CONCLUSIONS}

Our observations have shown that the complex of modern specialized medical care for the affected children with acute traumatic injuries of the teeth should be guided by their preservation, which ensures the subsequent normal formation of the dental-jaw apparatus. In the case of any traumatic dislocation of the tooth and fractures of the crown and root of the tooth, with the exception of multiple fractures, the injured tooth may be preserved with the help 
of qualified specialized care. To ensure these conditions, a long, reliable immobilization of the damaged tooth is required as soon as possible after injury. As a reliable splinting structure for the treatment of children with this pathology, we recommend the use of fiberglass tires.

\section{REFERENCES}

1. lefymenko V.P. Analiz arkhivnoho materialu kliniky kafedry khirurhichnoi stomatolohii ta shchelepno-lytsevoi khirurhii dytiachoho viku NMU za 2006-2010r.r. [Analysis of archival material of the Clinic of the Department of Surgical Dentistry and Maxillofacial Surgery of the Childhood of NMU for 2006-2010]. Sovremennaia stomatolohyia. 2011; 4; 76-79. (Ua)

2. Andreasen J.0., Lauridsen E., Andreasen F. M. Contradictions in the treatment of traumatic dental injuries and ways to proceed in dental trauma research. Dental Traumatology. 2010; 26 (1): 16-22.

3. Golochalova N.V., Suntsov V.G., Landinova V.D. i dr. Lechenie detey s ostroy travmoy postoyannyih zubov [Treatment of children with acute trauma of permanent teeth]. Klinicheskaya stomatologiya. 2002; 1: 46-48 (Ru)

4. Terehova T.N., Gorbacheva K.A. Travmaticheskie povrezhdeniya tverdyih tkaney zubov u detey [Traumatic injuries of dental hard tissues in children]. Sovremennaya stomatologiya. 2006; 1: 22-28. (Ru)

5. Nikolaev A.I. Elektroodontodiagnostika [Electroodontodiagnosis]. In Petrova E.V., Nikolaev A.I. Moskva: MEDpressinfom; 2014, p.40. (Ru)

6. Yakovenko L. M., Yefymenko V. P., Makarevych A. Yu. ta in. Travmy tymchasovykh i postiinykh zubiv u ditei (diahnostychni zakhody, likuvalna taktyka) [Injuries of temporary and permanent teeth in children (diagnostic measures, therapeutic tactics)]. Medychni perspektyvy. 2016; 21 (4): 106-115. (Ua)

7. Homenko L.A., Ostapko E.I., Bidenko N.V. Kliniko-rentgenologicheskaya diagnostika zabolevaniy zubov i parodonta u detey i podrostkov [Clinical and radiological diagnosis of diseases of the teeth and periodontium in children and adolescents]. Kiev: «Kniga plyus»; 2004, p. 200. (Ru)

8. Tkachenko P.I., Bilokon S.O., Hurzhii O.V. ta in. Adentiia, retentsiia i dystopiia zubiv v praktytsi khirurhichnoi stomatolohii ta ortodontii [Adentia, retention and dystopia of the teeth in the practice of surgical dentistry and orthodontics]. Stomatoloh. 2003; 12 (68): 29-31. (Ua)

9. Ebeleseder K. A., Glockner K. Posledstviya travmyi zubov [The consequences of dental injuries]. Kvintessentsiya. 2000.3:66-68. (Ru)

10. Firsova I.V., Suetenkov D.E., Gornova E.A. Primenenie adgezivnoy tehniki pri lechenii detey s travmami zubov [The use of adhesive technology in the treatment of children with dental injuries]. Materialyi 61-y konf. NOSMU SGMU. Saratov, 2000. 113-114. (Ru)
11. Stati T.N., Shadrina U.E. Klinicheskiy opyit lecheniya travm zubov s nesformirovannyimi kornyami [Clinical experience in the treatment of tooth injuries with unformed roots]. Problemyi stomatologii. 2009. 5:75-77. (Ru)

12. Sheshukova 0., Trufanova V., PolishchukT. et al. Monitoring of efficiency of dental caries management in children 's temporary teeth throughout Poltava oblast. Wiad Lek. 2018;71(3): 761-767.

Scientific work within the framework of the research work of the Ukrainian Medical Dental Academy "Restoration of dental health in patients with major dental diseases and their rehabilitation". State Registration No. 0111 U006300

\section{ORCID and contributionship:}

Valentina P. Trufanova - 0000-0002-7819-0188 ${ }^{A, D}$

Olha V. Sheshukova - 0000-0002-4739-4890 E,F

Nataliya O. Lyakhova - 0000-0003-0503-9935 ${ }^{\mathrm{C}}$

Tetiana V. Polishchuk - 0000-0003-1114-5830 ${ }^{B}$

Sofia S. Bauman - 0000-0002-9029-8968 ${ }^{B}$

Stanislav O. Stavytskyi - 0000-0002-8722-2591 ${ }^{B}$

\section{Conflicts of interest:}

Authors declare no conflict of interest

\section{CORRESPONDING AUTHOR Valentina P. Trufanova}

Shevchnka st. 23,36011, Poltava, Ukraine

tel:+380505910092

e-mail: trufanovav4@gmail.com

Received: 20.06 .2019

Accepted: 18.02 .2020

A - Work concept and design, B - Data collection and analysis, C - Responsibility for statistical analysis, D-Writing the article, $\mathbf{E}$-Critical review, $\mathbf{F}$ - Final approval of the article 